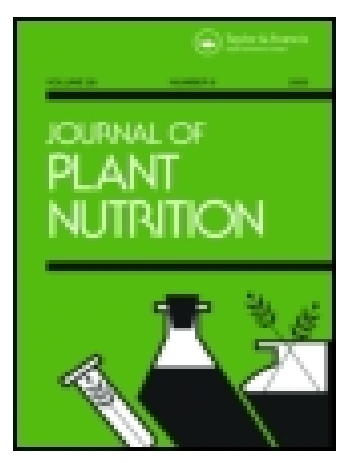

Journal of Plant Nutrition

ISSN: 0190-4167 (Print) 1532-4087 (Online) Journal homepage: http://www.tandfonline.com/loi/lpla20

\title{
Morpho-Pomologica and Chemical Properties of Pomegranate (Punica granatum L.) Cultivars in Iran
}

\section{Ali Mohammad Rahimi, Mehrdad Jafarpour \& Mohammad Pessarakli}

To cite this article: Ali Mohammad Rahimi, Mehrdad Jafarpour \& Mohammad Pessarakli (2017): Morpho-Pomologica and Chemical Properties of Pomegranate (Punica granatum L.) Cultivars in Iran, Journal of Plant Nutrition, DOI: 10.1080/01904167.2016.1269181

To link to this article: http://dx.doi.org/10.1080/01904167.2016.1269181

Accepted author version posted online: 25 Jan 2017.

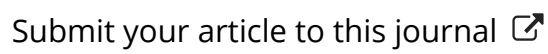

a

View related articles $\sqsubset$

View Crossmark data 


\title{
ACCEPTED MANUSCRIPT
}

\section{Morpho-Pomologica and Chemical Properties of Pomegranate (Punica granatum L.) Cultivars in Iran}

\author{
Ali Mohammad Rahimi ${ }^{1}$, Mehrdad Jafarpour ${ }^{1}$, and Mohammad Pessarakli ${ }^{2, *}$ \\ ${ }^{1}$ Department of Horticultural Science, College of Agriculture, Khurasgan University of \\ Esfahan. Iran \\ ${ }^{2}$ School of Plant Sciences, College of Agriculture \& Life Sciences, The University of \\ Arizona, Tucson, AZ 85721, USA
}

*Address Correspondence to Mohammad Pessarakli: pessarak@email.arizona.edu

\section{ABSTRACT}

This study was conducted to investigate the physico-chemical properties and antioxidant activity of five pomegranates fruit (Punica granatum L.) cultivars grown in Iran. Significant differences were found among the pomegranate cultivars for many of the properties studied. Results showed that, in particular, fruit diameter ranged from $63.63 \mathrm{~mm}$ (Syah) to $79.29 \mathrm{~mm}$ (Rabab), fruit volume from $153.3 \mathrm{~cm}^{3}$ (Syah) to $293.3 \mathrm{~cm}^{3}$ (Rabab), fruit density from $0.93 \mathrm{~g}$ $\mathrm{cm}^{-3}$ (Rabab) to $1.13 \mathrm{~g} \mathrm{~cm}^{-3}$ (Torsh Sefeed). Although Syah showed the lowest fruit weight (144.8 g), fruit yield $\left(8.28\right.$ ton $\left.\mathrm{ha}^{-1}\right)$ and fruit skin thickness $(1.55 \mathrm{~mm})$, Rabab had the highest fruit yield $\left(27.1\right.$ ton ha $\left.{ }^{-1}\right)$ and fruit skin thickness $(2.32 \mathrm{~mm})$. Juice volume was between 61.1 and $67.0 \mathrm{~cm}^{3}$. Percent of aril ranged from $59.64 \%$ (Rabab) to $75.3 \%$ (Syah) and weight of aril was between 108.9 and $199.8 \mathrm{~g}$. Also, results indicated that titratable acidity content varied from $0.39 \%$ (Syah) to $1.13 \%$ (Torsh Sefeed). The total soluble solids content varied from 12.67 -Brix (Torsh Sefeed) to $15.67{ }^{\circ}$ Brix (Zardeh Anar), pH values from 3.05 to 3.77, Electrical conductivity values from 2.8 to $3.14 \mathrm{dSm}^{-1}$ and vitamin $\mathrm{C}$ content from 59.25 to $69.52 \mathrm{mg} 100 \mathrm{~g}^{-}$ 


\section{ACCEPTED MANUSCRIPT}

1. The anthocyanins content was observed between 80.36 (Syah) and 216.97 (Zardeh Anar). The antioxidant activity of pomegranate cultivars ranged from $27.24 \%$ (Syah) to $84.04 \%$ (Torsh Sefeed). These results demonstrated that the cultivar was the major factor which influences the morpho-pomological and chemical (especially, antioxidant activity), properties in pomegranates.

\section{Keywords}

Antioxidant activity, Pomegranate, Juice, Cultivar, Fruit 


\section{ACCEPTED MANUSCRIPT}

\section{INTRODUCTION}

Pomegranate (Punica granatum L.) belongs to the Punicacea family (Harde et al., 1970). Pomegranate is one of the commercial horticultural fruits that is mainly cultivated in the North and South America, Mediterranean basin, southern Asia, and India (Ferrara et al., 2011). Recently, increasing demand for pomegranate products by consumers is specifically supported for its nutritional and medicinal characteristics (Lansky and Newman, 2007), due to the antioxidant characteristics of pomegranate fruit (Seeram et al., 2008) that contains anticarcinogenic (Bell and Hawthorne, 2008), antiviral (Kotwal, 2007), antimicrobial (Reddy et al., 2007), and anti atherosclerotic compounds that is able to reduce LDL oxidation and blood pressure (Aviram et al., 2004). These activities are principally due to the high levels of antioxidant activity and total polyphenols content of pomegranate (Tzulker et al., 2007). According to previous studies, the antioxidant activity in pomegranate juice was about 3-times higher than that of red wine or green tea (Gil et al., 2000), and 2-, 6- and 8-times higher than those in grape/cranberry, grapefruit, and orange juice, respectively (Rosenblat and Aviram, 2006).

Pomegranate fruit, as one of the native fruits in Iran, production has increased due to increasing evidence on its high value of beneficial materials. Iran is one of the most important producers of pomegranate $\left(67 \times 10^{4}\right.$ tons in 2005$)$ and exporters in the world (Anonymous, 2005). In spite of different pomegranate cultivars grown in Iran, only a few published results on the characteristics of the cultivars in the literature are available. Thus, the main objective of this study was to investigate and compare morpho-pomological characteristics and the levels of 


\section{ACCEPTED MANUSCRIPT}

antioxidants, total polyphenols, and vitamin $\mathrm{C}$ in five cultivars of pomegranate in order to better characterize cultivars that can be utilized for pomegranate cultivation.

\section{MATERIALS AND METHODS}

\section{Pomegranate Cultivars and Fruits Collections}

The collection of pomegranate fruits was conducted in the years 2014. In the present study, five pomegranate cultivars were studied: Syah Arsanjani, Zardeh Anar Arsanjani, Torsh Sefeed Arsanjan, Kalantari Arsanjan, and Rabab Arsanjan. The pomegranate fruits were collected from adult trees $(\approx 25$-year-old) located in private small orchards. Commercially ripe fresh fruits were harvested in September 2014 from different mature trees randomly selected to represent the population of the plantation from Fars province, Iran. Fruits were transported to the laboratory soon after harvest, where pomegranates with defects were discarded. About $2 \mathrm{~kg}$ of pomegranate fruit was sampled for each cultivar. The fruits were kept at $4{ }^{\circ} \mathrm{C}$ until analysis. Three replicates were maintained for each analysis.

\section{Physical Properties}

Four fruits of each cultivar were individually investigated for physical properties.

The weight of the fruit and aril (fresh weight) were determined by weighting theses in the air on a precision digital balance with an accuracy of $0.001 \mathrm{~g}$. Fruit volume was determined by a liquid displacement method. The density of the fruit was obtained by the ratio of weight to volume. The fruit diameter and fruit skin thickness were measured with a digital vernier caliper (Tehranifar et al., 2010).

\section{Chemical Properties}




\section{ACCEPTED MANUSCRIPT}

The juices were analyzed for electrical conductivity (EC), $\mathrm{pH}$, titratable acidity (TA), total soluble solids (TSS), vitamin C content, total anthocyanins, and total antioxidant activity. For electrical conductivity determinations, the juice samples were homogenized and measured with a Conductometer (Metrohm). The $\mathrm{pH}$ measurements were performed by a digital $\mathrm{pH}$ meter (Metrohm). The titratable acidity (TA) was determined using titration to $\mathrm{pH} 8.1$ with $0.1 \mathrm{M}$ sodium hydroxide $(\mathrm{NaOH})$ solution and expressed as $\mathrm{g}$ of citric acid per $100 \mathrm{~g}$ of juice (AOAC, 1984). The total soluble solids (TSS) were measured with a digital refractrometer (Erma, Tokyo, calibrated using distilled water). The data were reported as ${ }^{\circ}$ Brix. The concentration of vitamin $\mathrm{C}$ was measured by applying the method described by Ruck (1963). Results were expressed as $\mathrm{mg} / 100 \mathrm{~g}$ of juice.

Measurement of total anthocyanin was determined according to modified Wagner (1979) method using acidified ethanol. Briefly, $0.1 \mathrm{~g}$ of the arils was homogenized in $2.5 \mathrm{ml}$ acidified ethanol and then kept at $25^{\circ} \mathrm{C}$ for $24 \mathrm{~h}$ in the dark. The extract was centrifuged at $4000 \mathrm{~g}$ for 10 min at room temperature. The absorbance was measured spectrophotometrically at $550 \mathrm{~nm}$. The extinction coefficient $33000\left(\mathrm{~mol}^{-1} \mathrm{~cm}^{-1}\right)$ was applied to calculate the content of total anthocyanin.

Antioxidant activity was determined according to the 2,2-diphenyl-1-picrylhydrazyl (DPPH) method described by Brand-Williams et al. (1995). Briefly, $100 \mu 1$ of pomegranate juice diluted in the ratio of 1:100 with methanol: water (6:4) was mixed with $2 \mathrm{ml}$ of $0.1 \mathrm{mM}$ DPPH in methanol. The mixtures were shaken vigorously and left to stand for $30 \mathrm{~min}$. Absorbance of the resulting solution was measured at $517 \mathrm{~nm}$ by a Cecil 2010 UV-visible spectrophotometer. The 


\section{ACCEPTED MANUSCRIPT}

reaction mixture without DPPH was used for the background correction. The antioxidant activity was calculated using the following equation (Equation 1):

Antioxidant activity $(\%)=\lfloor 1-($ sample $517 \mathrm{~nm} /$ control $517 \mathrm{~nm})\rfloor \times 100$

Antioxidant activity was determined according to the method described by BrandWilliams et al. (1995). Briefly, $0.1 \mathrm{ml}$ of pomegranate juice diluted in the ratio of 1:100 with methanol: water was mixed with $2 \mathrm{ml}$ of $0.1 \mathrm{mM}$ 2,2-diphenyl-1-picrylhydrazyl (DPPH) in methanol. The mixtures were shaken vigorously and left to stand for $30 \mathrm{~min}$. The absorbance of the resulting solution was measured spectrophotometrically at $517 \mathrm{~nm}$. The reaction mixture without DPPH was used for the background correction. The antioxidant activity was calculated using the following equation (Equation 2):

Antioxidant activity $(\%)=\lfloor 1-($ sample $517 \mathrm{~nm} /$ control $517 \mathrm{~nm})\rfloor \times 100$. (2)

\section{Statistical Analyses}

Experimental data were analyzed by SAS software Version 9.1 using analysis of variance (ANOVA) and differences among means were determined for significance at $\mathrm{P}<0.05$ using Duncan Multiple Range test.

\section{ESULTS AND DISCUSSION}

\section{Physical Properties}

The physical characteristics of five pomegranate cultivars analyzed are listed in Table 1. Results indicated that significant differences $(\mathrm{p}<0.05)$ were detected in all analyzed properties. In particular, fruit diameters ranged from $63.63 \mathrm{~mm}$ (Syah) to $79.29 \mathrm{~mm}$ (Rabab). These values were lower than those reported by other studies. It was previously reported demonstrated that the fruit diameter of pomegranates grown in Iran are between 68-86.9mm (Sarkhosh et al., 2009) 


\section{ACCEPTED MANUSCRIPT}

and 64.9-86.88mm (Tehranifar et al., 2010). Celik and Erasl (2009) investigated physical characteristics of pomegranate cv. 'Eksinar' and indicated that fruit weight and volume were between 154.4 to $289.5 \mathrm{~g}$ and from 150.9 to $295.8 \mathrm{~cm}^{3}$, respectively. Also, fruit dimensions varied from 52.9 to $75.0 \mathrm{~mm}$ for length, 60.6 to $85.9 \mathrm{~mm}$ for width and 63.4 to $81.4 \mathrm{~mm}$ for thickness.

Results indicated that 'Syah' cultivar had the lowest fruit volume from $153.3 \mathrm{~cm}^{3}$ and 'Rabab' $\left(293.3 \mathrm{~cm}^{3}\right)$ had the highest fruit volume (Table 1). These values were lower than those reported by Tehranifar et al. (2010) who found the lowest $\left(204.24 \mathrm{~cm}^{3}\right)$ and the highest $\left(341.35 \mathrm{~cm}^{3}\right)$ fruit volume were observed in Iranian pomegranate cultivars.

As shown in Table 1, variations in fruit density were observed among the studied cultivars (0.93 $\mathrm{g} \mathrm{cm}^{-3}$ (Rabab) to $1.13 \mathrm{~g} \mathrm{~cm}^{-3}$ (Torsh Sefeed)). However, Akbarpour et al. (2009) observed that the fruit density of pomegranate cultivars ranged between $0.91 \mathrm{~g} \mathrm{~cm}^{-3}$ and $1.04 \mathrm{~g}$ $\mathrm{cm}^{-3}$.

Although 'Syah' showed the lowest fruit weight $(144.8 \mathrm{~g})$, fruit yield $\left(8.28 \mathrm{ton} \mathrm{ha}^{-1}\right)$ and fruit skin thickness $(1.55 \mathrm{~mm})$, Rabab had the highest fruit yield $\left(27.1 \mathrm{ton} \mathrm{ha}^{-1}\right)$ and fruit skin thickness $(2.32 \mathrm{~mm})$ (Table 1). Tehranifar et al. (2010) studied twenty Iranian pomegranate cultivars and found that the average fruit weight of pomegranate cultivars ranged between 196.89 $\mathrm{g}$ and $315.28 \mathrm{~g}$. It was previously reported that the fruit weights of pomegranates grown in Iran are between $164.89 \mathrm{~g}$ and $375.76 \mathrm{~g}$ (Sarkhosh et al., 2009). Ferrara et al. (2011) observed that fruit weight ranged from 168.9 to $574.9 \mathrm{~g}$. However, variation in fruit weight depends on the cultivar and ecological condition (Shulman et al., 1984). In the present study skin thicknesses of 


\section{ACCEPTED MANUSCRIPT}

the fruits were lower than values reported by Tehranifar et al. (2010) who found the fruit skin thicknesses were between 3.13 and $5.36 \mathrm{~mm}$.

As shown in Table 1, results indicated that juice volume was between 61.1 and $67.0 \mathrm{~cm}^{3}$. Percent of aril ranged from 59.64\% (Rabab) to $75.3 \%$ (Syah) and weights of arils were between 108.9 and 199.8 g. However, Ferrara et al. (2011) reported that there were significant differences found in juice volume among genotypes and ranged from 65.2 to $72.2 \mathrm{~cm}^{3}$. Varasteh et al. (2009) evaluated important fruit properties of five pomegranate cultivars in Iran and found that 'Malase-yazdi' had the highest fruit weight, volume, length, diameter, aril percent and juice content (699.94 g, $715.60 \mathrm{~cm}^{3}, 103.55 \mathrm{~mm}, 109.50 \mathrm{~mm}, 73.88$. and $58.31 \%$, respectively). The results for the physical properties of the pomegranate cultivars of the present study confirmed that the five cultivars were different in all investigated properties. 'Rabab' cultivar seems the most promising in combined more fruit size, fruit weight and fruit juice.

\section{Chemical Properties}

The results of the electrical conductivity, $\mathrm{pH}$, Titratable acidity, total soluble solids, vitamin $\mathrm{C}$, total anthocyanins and antioxidant activity of the five pomegranates from the different cultivars are given in Table 2. Generally, these characteristics were significantly $(\mathrm{P}<0.05)$ different among pomegranate cultivars (Table 2).

The electrical conductivity of pomegranate juice ranged from $2.80-3.14 \mathrm{dS} / \mathrm{m}$, the highest was found in 'Syah' and the lowest in 'Zardeh Anar' (Table 2). Sarkhosh et al. (2009) studied Iranian soft-seed pomegranate and they reported that the electrical conductivities of the pomegranate juice were between 0.3 and $3.4 \mathrm{mmoh} / \mathrm{cm}$. 


\section{ACCEPTED MANUSCRIPT}

The $\mathrm{pH}$ values ranged between 3.05 and 3.77 (Table 2). The $\mathrm{pH}$ values obtained in the current study are greater than those reported by Cam et al. (2009) on pomegranate cultivars grown in Turkey. However, Akbarpour et al. (2009) indicated that the $\mathrm{pH}$ values of the pomegranate juice ranged from 2.75 to 4.14 .

Also, the results indicated that titratable acidity content varied from $0.39 \%$ (Syah) to 1.13\% (Torsh Sefeed). Tehranifar et al. (2010) found that titratable acidity content ranged from

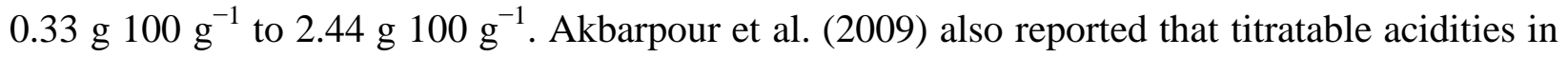
pomegranate juices were $0.35 \%$ and $3.36 \%$.

The total soluble solids content ranged from $12.67-15.67^{\circ}$ Brix, the highest was found in 'Zardeh Anar' and the lowest in 'Torsh Sefeed'. This result is lower than values observed (16-19 -Brix) by Poyrazoglu et al. (2002), while our results were approximately in agreement with values reported by Fadavi et al. (2005) (10-16.5 •Brix), Martinez et al. (2006) (12.36-16.32 ${ }^{\circ}$ Brix) for five Spanish cultivars and those reported by Tehranifar et al. (2010) for cultivars grown in Iran. Tehranifar et al. (2010) observed that the highest total soluble solids content was found in 'Torsh Shavar Ferdows' (15.07 ${ }^{\circ}$ Brix) and the lowest one was found in 'Agha Mandali Save’ (11.37 •Brix).

As shown in Table 2 the concentration of vitamin $\mathrm{C}$ varied greatly among the genotypes,

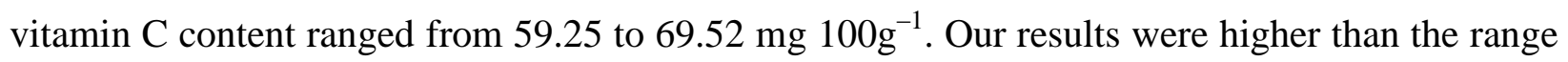
(9.91 $\mathrm{mg} 100 \mathrm{~g}^{-1}$ to $20.92 \mathrm{mg} 100 \mathrm{~g}^{-1}$ ) reported by Tehranifar et al. (2010) and Kulkarni and Aradhya (2005). However, Ferrara et al. (2011) observed that there were significant differences found in concentration of vitamin C among the genotypes and ranged from 89.0 to $236.3 \mathrm{mg} / \mathrm{L}$. 


\section{ACCEPTED MANUSCRIPT}

The results for total anthocyanins of the pomegranate from different cultivars are displayed in Table 2. A significant variation in total anthocyanins content was observed among the five varieties of pomegranate investigated and the values ranged from 80.36 (Syah) to 216.97 (Zardeh Anar) (Table 2). Anthocyanins are a member of the phenolics compounds that are wellknown for their antioxidant activity (Tehranifar et al., 2010). These results showed that the contents of total anthocyanins varied among different cultivars of pomegranate and there was a high genetic heterogeneity found within the investigated cultivars.

As shown in Table 2, it was observed that 'Syah' cultivar had surprisingly the lowest antioxidant activity (27.24\%) and Torsh Sefeed (84.04\%) had the highest antioxidant activity. In this study antioxidant activity was higher than values reported by Tehranifar et al. (2010) who found that the antioxidant activity values ranged from $15.59 \%$ to $40.72 \%$. Antioxidant activity has been reported for eight pomegranate juices in Iran. 18.6-42.8\% (Mousavinejad et al., 2009) and seven pomegranate juices in Turkey. 10.37-67.46\% (Tezcan et al., 2009). There was a significant and positive correlation $(\mathrm{r}=0.54)$ between anthocyanins content and antioxidant activity.

Correlation coefficients (r) between the variables investigated are shown in Table 3. Titratable acidity (TA) and anti-oxidant activity were significantly correlated with $\mathrm{pH}$ at the 0.01 probability level $(\mathrm{p}<0.01),(\mathrm{r}=0.93 * *$ and $\mathrm{r}=0.92 * *$, respectively, Table 3$)$. TA was also significantly correlated with anti-oxidant activity at the 0.01 probability level $(\mathrm{p}<0.01)$, $(\mathrm{r}=0.914 * *$, Table 3$)$. However, the correlation between TA and EC was significant only at the 0.05 probability level $(\mathrm{p}<0.05),\left(\mathrm{r}=0.56^{*}\right.$, Table 3$)$.

\section{CONCLUSIONS}




\section{ACCEPTED MANUSCRIPT}

The results of the present study indicated that statistically significant differences were observed in morpho-pomological and chemical properties of the various pomegranate cultivars. Therefore, cultivar type plays a significant role in terms of physico-chemical properties of the pomegranate juice. Among the five cultivars studied, Rabab showed the highest content of antioxidant activity, total anthocyanins, and vitamin $\mathrm{C}$ which are suitable for fresh consumption and human health benefits. 


\section{ACCEPTED MANUSCRIPT}

\section{REFERENCES}

Akbarpour, V., Hemmati, K., Sharifani, M. 2009. Physical and chemical properties of pomegranate (Punica granatum L.) fruit in maturation stage. American-Eurasian Journal of Agriculture and Environmental Science, 6: 411-416.

Anonymous, 2005. Statistical Book of Agricultural of Iran. Iranian Statistical Centre, Tehran, Iran.

AOAC, 1984. Official Methods of Analysis, 14th ed. Association of Official Analytical Chemists, Washington DC, U.S.A.

Aviram, M., Rosenblat, M., Gaitini, D., Nitecki, S., Hoffman, A., Dornfeld, L., Volkova, N., Presser, D., Attias, J., Liker, H., Hayek, T. 2004. Pomegranate juice consumption for 3 years by patients with carotid artery stenosis reduces common carotid intima-media thickness, blood pressure and LDL oxidation. Clinical Nutrition, 23: 423-433.

Bell, C., Hawthorne, S. 2008. Ellagic acid, pomegranate and prostate cancer a mini review. Journal of Pharmacy and Pharmacology, 60: 139-144.

Brand-Williams, W. Cuvelier, M.E., Berset, C. 1995. Use of a free radical method to evaluate antioxidant activity. Food Science and Technology, 28: 25-30.

Cam, M., Hisil, Y., Durmaz, D. 2009. Characterization of pomegranate juices from ten cultivars grown in Turkey. International Journal of Food Protection, 12: 388-395. 


\section{ACCEPTED MANUSCRIPT}

Celik, A. and S. Erasl. 2009. Some physical properties of pomegranate cv. Eksinar. International Agrophysics, 23: 295-298.

Fadavi, A., Barzegar, M., Azizi, M.H., Bayat, M. 2005. Physicochemical composition of 10 pomegranate cultivars (Punica granatum L.) grown in Iran. International Food Science and Technology, 11 (2): 113-119.

Ferrara, G., Cavoski, I., Pacifico, A., Tedone, L., Mondelli, D. 2011. Morpho-pomological and chemical characterization of pomegranate (Punica granatumL.) genotypes in Apulia region, south eastern Italy. Scientia Horticulturae, 130: 599-606.

Gil, M.I., Tomas-Barberan, F.A., Hess-Pierce, B., Holcroft, D.M., Kader, A.A. 2000. Antioxidant activity of pomegranate juice and its relationship with phenolic composition and processing. Journal of. Agriculture and Food Chemistry, 48: 4581-4589.

Harde, H., W. Schumacher, F. Firbas and D. Deffer. 1970. Strasburg's Textbook of Botany. Chaucer, London.

Kotwal, G.J. 2007. Genetic diversity-independent neutralization of pandemic viruses (e g. HIV), potentially pandemic (e.g. H5N1 strain of influenza) and carcinogenic (e.g. HBV and $\mathrm{HCV}$ ) viruses and possible agents of bioterrorism (variola) by enveloped virus neutralizing compounds (EVNCs). Vaccine, 26: 3055-3058.

Kulkarni, A.P., Aradhya, S.M. 2005. Chemical changes and antioxidant activity in pomegranate arils during fruit development. Food Chemistry, 93: 319-324. 


\section{ACCEPTED MANUSCRIPT}

Lansky, P.E., Newman, R.A. 2007. Punica granatum (pomegranate) and its potential for prevention and treatment of inflammation and cancer. Journal of Ethnopharmacology, 109: 177-206.

Martinez, J. J., Melgarejo, P. Hernandez, F., Salazar, D. M., \& Martinez, R. 2006. Seed characterization of five new pomegranate (Punica granatum L.) varieties. Scientia Horticulturae, 110: 241-246.

Mousavinejad, G., Emam-Diomeh, Z., Rezaei, K., Khodaparast, M.H.H. 2009. Identification and quantification of phenolic compounds and their effects on antioxidant activity in pomegranate juices of eight Iranian cultivars. Food chemistry, 115: 1274-1278.

Poyrazoglu, E., Gokmen, V., Artik, N. 2002. Organic acids and phenolic compounds in pomegranates (Punica granatum L.) grown in Turkey. Journal of Food compounds. Analysis, 15: 567-575.

Reddy, M.K., Gupta, S.K., Jacob, M.R., Khan, S.I., Ferreira, D., 2007. Antioxidant, antimalarial and antimicrobial activities of tannin-rich fractions, ellagitannins and phenolic acids from Punica granatum L. Planta Medicinae, 73: 461-467.

Rosenblat, M., Aviram, M. 2006. In: Seeram, N.P., Heber, D. (Eds.), In Vitro Studies, in Pomegranates: Ancient Roots to Modern Medicine. Taylor and Francis Group, New York, pp. 31-43. 


\section{ACCEPTED MANUSCRIPT}

Sarkhosh, A., Zamani, Z., Fatahi, R., Ranjbar, H. 2009. Evaluation of genetic diversity among Iranian soft-seed pomegranate accessions by fruit characteristics and RAPD markers. Scientia. Horticulturae, 121: 313-319.

Seeram, N.P., Aviram, M., Zhang, Y., Henning, S., Feng, L., Dreher, M., Heber, D. 2008. Comparison of antioxidant potency of commonly consumed polyphenol-rich beverages in the United States. Journal of Agriculture and Food Chemistry, 56: 1415-1422.

Shulman, Y., Fainbertein, L., Lavee, S. 1984. Pomegranate fruit development and maturation. Journal of Horticulture Sciences, 48: 293-296.

Tehranifar, A., Zarei, M., Nemati, Z., Esfandiyari, B., Vazifeshenas, M.R. 2010. Investigation of physic-chemical properties and antioxidant activity of twenty Iranian pomegranate (Punica granatum L.) cultivars. Scientia Horticulturae. 126, 180-185.

Tezcan, F., Gultekin-Ozguven, M., Diken, T., Ozcelik, B., Erim, F.B. 2009. Antioxidant activity and total phenolic, organic acid and sugar content in commercial pomegranate juices. Food Chemistry, 115: 873-877.

Tzulker, R., Glazer, I., Bar-Ilan, I., Holland, D., Aviram,M., Amir, R. 2007. Antioxidant activity, polyphenol content and related compounds in different fruit juices and homogenates prepared from 29 different pomegranate accessions. Journal of Agriculture and Food Chemistry, 55: 9559-9570. 


\section{ACCEPTED MANUSCRIPT}

Varasteh, F., K. Argani, Z. Zamani and A. Mohseni. 2009. Evaluation of the most important characteristics of some commercial pomegranate (Punica granatum L.) cultivars grown in Iran. Acta Horticulturae, 818: 103-1038.

Wagner G.J. 1979. Content and vacuole/extra vacuole distribution of neutral sugars free amino acids and anthocyanins in protoplast. Plant Physiology, 64: 88-93. 


\section{ACCEPTED MANUSCRIPT}

TABLE 1. Some physical properties of five Iranian pomegranate cultivars

\begin{tabular}{|l|l|l|l|l|l|l|l|l|l|}
\hline Cultivars & $\begin{array}{l}\text { Fruit } \\
\text { diamete }\end{array}$ & $\begin{array}{l}\text { Fruit } \\
\text { volum }\end{array}$ & $\begin{array}{l}\text { Fruit } \\
\text { densit }\end{array}$ & $\begin{array}{l}\text { Fruit } \\
\text { weight }\end{array}$ & $\begin{array}{l}\text { Fruit } \\
\text { yield }\end{array}$ & $\begin{array}{l}\text { Juice } \\
\text { volum }\end{array}$ & $\begin{array}{l}\text { Fruit } \\
\text { skin }\end{array}$ & $\begin{array}{l}\text { Percen } \\
\text { t of aril }\end{array}$ & $\begin{array}{l}\text { Weigh } \\
\mathrm{t} \\
\text { of }\end{array}$ \\
\hline Syah & $63.63 \mathrm{~b}$ & 153.27 & $0.95 \mathrm{c}$ & 144.8 & 8.28 & 62.40 & $1.55 \mathrm{c}$ & $75.30 \mathrm{a}$ & 108.95 \\
\hline Zardeh & $69.04 \mathrm{~b}$ & 189.33 & $1.04 \mathrm{~b}$ & 196.7 & 11.5 & $66.07 \mathrm{a}$ & $1.59 \mathrm{c}$ & 71.07 & 139.58 \\
\hline Torsh & $77.59 \mathrm{a}$ & 251.33 & $1.13 \mathrm{a}$ & 282.7 & 12.2 & $66.80 \mathrm{a}$ & $1.92 \mathrm{~b}$ & 70.52 & 199.87 \\
\hline Kalantari & $66.68 \mathrm{~b}$ & 180.00 & $0.96 \mathrm{c}$ & 172.6 & 9.67 & 61.13 & $1.60 \mathrm{c}$ & 68.34 & 117.89 \\
\hline Rabab & $79.29 \mathrm{a}$ & 293.33 & $0.93 \mathrm{c}$ & 271.9 & 27.0 & $67.00 \mathrm{a}$ & $2.32 \mathrm{a}$ & $59.64 \mathrm{c}$ & 162.08 \\
\hline
\end{tabular}

In each column, the values followed by at least one common letter character are not

statistically different at 5\% probability level, according to the Duncan Multiple Range test 


\section{ACCEPTED MANUSCRIPT}

TABLE 2. Some chemical properties of five Iranian pomegranate cultivars

\begin{tabular}{|l|l|l|l|l|l|l|l|}
\hline Cultivars & $\begin{array}{l}\text { Electrical } \\
\text { conductivity } \\
(\mathrm{dS} / \mathrm{m})\end{array}$ & $\mathrm{pH}$ & $\begin{array}{l}\text { Titratable } \\
\text { acidity } \\
\text { (TA) }\end{array}$ & $\begin{array}{l}\text { Total } \\
\text { soluble } \\
\text { solids }\end{array}$ & $\begin{array}{l}\text { Vitamin } \\
\mathrm{C}\end{array}$ & $\begin{array}{l}\text { Total } \\
\text { anthocyanins }\end{array}$ & $\begin{array}{l}\text { Total } \\
\text { antioxidant } \\
\text { activity }\end{array}$ \\
\hline Syah & $3.14 \mathrm{a}$ & 3.77 & $0.39 \mathrm{~d}$ & $14.27 \mathrm{~b}$ & $59.55 \mathrm{~b}$ & $80.36 \mathrm{c}$ & $27.24 \mathrm{~d}$ \\
\hline Zardeh & $2.80 \mathrm{~d}$ & 3.42 & $0.86 \mathrm{c}$ & $15.67 \mathrm{a}$ & $59.25 \mathrm{~b}$ & $216.97 \mathrm{a}$ & $70.98 \mathrm{c}$ \\
\hline Torsh & $2.92 \mathrm{c}$ & 3.05 & $1.13 \mathrm{a}$ & $12.67 \mathrm{c}$ & $60.13 \mathrm{~b}$ & $82.91 \mathrm{c}$ & $84.04 \mathrm{a}$ \\
\hline Kalantari & $3.02 \mathrm{~b}$ & 3.29 & $0.97 \mathrm{~b}$ & $14.80 \mathrm{~b}$ & $69.52 \mathrm{a}$ & $212.24 \mathrm{a}$ & $77.91 \mathrm{~b}$ \\
\hline Rabab & $3.04 \mathrm{~b}$ & 3.25 & $0.84 \mathrm{c}$ & $13.93 \mathrm{~b}$ & $66.88 \mathrm{a}$ & $183.52 \mathrm{~b}$ & $83.69 \mathrm{a}$ \\
\hline
\end{tabular}

In each column, the values followed by at least one common letter character are not statistically different at $5 \%$ probability level, according to the Duncan test 


\section{ACCEPTED MANUSCRIPT}

TABLE 3. Pearson correlation coefficients (r) between variables investigated.

\begin{tabular}{|l|l|l|l|l|l|l|l|}
\hline Properties & $\mathrm{pH}$ & $\mathrm{EC}$ & $\mathrm{TSS}$ & Vitamin C & $\mathrm{TA}$ & $\mathrm{Antioxidan}$ & Anthocyani \\
\hline $\mathrm{pH}$ & 1 & & & & & & $\mathrm{~ns}$ \\
\hline EC & 0.41 & 1 & & & & & \\
\hline TSS & 0.43 & -0.19 & 1 & & & & \\
\hline Vitamin C & -0.31 & 0.27 & 0.13 & 1 & & & \\
\hline TA & $-0.93^{* *}$ & $-0.56^{*}$ & -0.31 & 0.21 & 1 & & \\
\hline Antioxidant & $-0.92^{* *}$ & -0.46 & -0.21 & 0.39 & $0.914^{* *}$ & 1 & \\
\hline Anthocyanins & -0.20 & -0.34 & $0.66^{* *}$ & 0.51 & 0.30 & $0.54^{*}$ & 1 \\
\hline
\end{tabular}

*Correlation is significant at the 0.05 level.

**Correlation is significant at the 0.01 level. 